\title{
Energiewende: german energy policy in times of green transition
}

\section{Energiewende: política energética alemã em tempos de transição verde}

DOI: $10.21530 /$ ci.v12n3.2017.649

Solange Reis ${ }^{1}$

\begin{abstract}
Germany has developed an ambitious strategy to increase the share of renewable sources in its energy matrix and to enable the transition to a green industrial paradigm. Known as Energiewende, the policy implied profound structural transformations in the energy system. Participation of the residents and of small entrepreneurs stands out among its particularities. The state leads the transitional project by mediating the divergent interests among social and economic agents. The challenge is to maintain social consensus despite unequal costs. Individual consumers, farmers and some industries faced high electricity prices while energy-intensive industries were exempt, a disparity that attracts much criticism. The project involves dismantling nuclear power plants, which leads to increasing use of coal or natural gas. Another challenge is to keep investments on track. This article presents the topic from its historical development and shows that German energy strategy surpasses moral and economic concerns. Beyond economics and energy security, it is a broader plan to place the country in the vanguard transition to green capitalism.
\end{abstract}

Keywords: Energiewende; Germany; Renewable Energy; Green Capitalism.

\section{Resumo}

A Alemanha desenvolveu uma estratégia ambiciosa para aumentar a participação de fontes renováveis na matriz energética e viabilizar a transição para um paradigma verde. Conhecida como Energiewende, essa política implicou profundas transformações estruturais no sistema energético. A participação da população e de pequenos empreendedores destaca-se entre as suas particularidades. O Estado conduz o projeto, mediando interesses divergentes entre

1 Programa de Pós-Graduação em Relações Internacionais San Tiago Dantas (Unesp, Unicamp, PUC-SP); Instituto Nacional de Ciência e Tecnologia para Estudos sobre os Estados Unidos (INCT-Ineu), ambos em São Paulo/SP, Brasil. E-mail: reissolange@gmail.com

Artigo submetido em 20/02/2017 e aprovado em 20/09/2017. 
agentes sociais e econômicos. O desafio é manter o consenso social apesar dos custos desiguais. Consumidores individuais, agricultores e algumas indústrias sofrem aumento no preço da eletricidade, enquanto o setor industrial intensivo em energia recebe isenções, situação que gera muitas críticas. O projeto envolve o fechamento do parque nuclear, o que leva ao aumento no uso de carvão ou gás. Outro desafio é manter os investimentos necessários. $\mathrm{O}$ artigo apresenta o tema a partir de seu desenvolvimento histórico, indicando que a estratégia ultrapassa preocupações morais e econômicas atuais. Para além da economia e da segurança energética, o projeto posiciona o país na vanguarda da transição para o capitalismo verde.

Palavras-chave: Energiewende; Alemanha; Energia Renovável; Capitalismo Verde.

\section{Introduction}

Will an industrialized country that consumes a substantial amount of energy and still has pretty high emissions manage to achieve the ambitious goals without jeopardizing the security of supply, triggering a massive increase in energy prices and, above all, scaring off power-intensive branches of industry? (DEUTSCHE BANK, 2012, p. 2)

At some point in one Deutsche Bank report, these questions arise about the viability of the German energy policy called Energiewende. Similar doubts foster debates in various academic, political, and communication spheres. At the heart of the issue lies the effectiveness of the German strategy to achieve high rates of electricity from renewable sources and to reduce greenhouse gas emissions, while eliminating the use of nuclear energy.

Energiewende comprises a set of legislation, incentives and investments to increase the share of renewable sources in electricity generation and to combat climate change. Its design implies costs and transformations that require constant engagement of economic and social sectors.

Although the government is the architect of this transformation, the horizontality of the operational process involves individuals and city councils, as well as small and large entrepreneurs. The strategy started before German Reunification, surviving governments of different ideological orientations. The environmental motivations coincide with those of the European Union (EU), but the project reflects the German conception that energy and industrial policy go side by side.

Given the growing integration of the German market with the European energy infrastructure, Energiewende impacts neighboring countries. Some of them 
see German energy policy with good anticipation; other nations perceive it as a catalyst for regional asymmetries. According to some critics, with the excuse for reducing domestic and regional dependence on external fossil resources, Germany plans to lead the common market by becoming a major exporter of secondary energy and leveraging markets for its green technology industry.

With regard to external dependence, the option to end nuclear energy implies more gas consumption in the short and medium term. Good for Russia, bad for transatlantic relations, significant for international politics.

The article summarizes its historical and regulatory points, and indicates some possible effects for Germany's foreign energy policy. It highlights the role of the state as a transformative agent towards a new model of industrialization in the $21^{\text {st }}$ Century. As the last section of this paper shows, a similar sort of Schumpeterian green transition is being adapted and advanced by emerging countries such as China as a way to sustain its enormous economic needs.

\section{History}

The Energiewende has ambitious goals and implies structural and regulatory transformations in the way that energy is generated, subsidized, distributed and remunerated.

Figure 1: Goals and Results

\begin{tabular}{|c|c|c|c|c|c|}
\hline Emission reduction goals & $\mathbf{2 0 2 0}$ & $\mathbf{2 0 3 0}$ & $\mathbf{2 0 4 0}$ & $\mathbf{2 0 5 0}$ & Situation in 2014 \\
\hline $\begin{array}{c}\text { Reduction of greenhouse gas } \\
\text { emission (year basis 1990) }\end{array}$ & $-40 \%$ & $-55 \%$ & $-70 \%$ & $-80 \%$ & $-26,4 \%$ \\
\hline $\begin{array}{c}\text { Renewable sources in total } \\
\text { energy consumption }\end{array}$ & $+18 \%$ & $+30 \%$ & $+45 \%$ & $+60 \%$ & $+12,4 \%(* 2013)$ \\
\hline $\begin{array}{c}\text { Renewable sources in total } \\
\text { power consumption }\end{array}$ & - & $+40 \%$ & $+55 \%$ & $+80 \%$ & $+27,3 \%$ \\
\hline $\begin{array}{c}\text { Reduction in primary energy } \\
\text { consumption (year basis 2008) }\end{array}$ & $-20 \%$ & - & - & $-50 \%$ & $-9,1 \%$ \\
\hline $\begin{array}{c}\text { Reduction in power consumption } \\
\text { (year base 2008) }\end{array}$ & $-10 \%$ & - & - & $-25 \%$ & $-4,8 \%$ \\
\hline
\end{tabular}

Source: AGORA, 2015; BUCHAN, 2012. 
The project stands on four pillars: (a) public incentives for renewable energy as primary source for electricity; (b) infrastructure modernization, (c) decentralization of supply and consumer autonomy; (d) closing of the nuclear industry. Structured around the increase of wind and solar energy, it proposes to eliminate the use of nuclear power plants until 2022 and drastically reduce the percentage of coal in the energy matrix until 2050.

German government took the first steps in that direction in the 1970s, when oil shocks took place and environmental protection ideas gained track. As many other countries did, Germany also sought to diversify its oil suppliers beyond the Middle East. That led to the intensification of its relations with the Soviet Union in the wake of the Ostpolitik and the gradual incorporation of "red gas" (Russian) into West Germany energy matrix (HÖGSELIUS, 2013).

At the same time, it sought to increase energy security through renewable sources and the creation of public agencies for planning and implementing clean energy policies. Although the term "energy security" comprises various definitions, from geopolitical to economical sense, this paper consider it as low vulnerability of vital energy systems (CHERPA; JEWELL, 2014).

Investments in nuclear power grew at that time too, but the resistance of the population represented a constant barrier to the nuclear sector. Anti-nuclear feelings since the 1970s partly explain why Energiewende is welcome by civil society today notwithstanding the economic and social costs of the process.

The concept of "energy transition" was borrowed from the book "EnergieWende: Wachstum und Wohlstand ohne Erdol und Uran" about growth and well-being without oil and uranium. The book argued that the fundamental and radical change in the energy policy of the Federal Republic of Germany (and of the industrialized countries in general) has become indispensable" (KRAUSE, BOSSEL, REISSMANN, 1980, p. 13).

The Green Party's (Die Grünen) first election for Federal Parliament in 1983 and the Chernobyl nuclear accident in Ukraine three years later stimulated the establishment of the Federal Ministry for the Environment, Nature Conservation, Construction and Nuclear Safety (Bundesministerium für Umwelt, Naturshutz, Bau and Reaktorsicherheit), raising the issue in the hierarchy of the institutional agenda.

Since then, a set of initiatives at federal, state and municipal levels have redesigned the rules of the electric sector. Those actions included fostering production of clean energy at residences and the dismantling of operational 
monopolies. The issue gained urgency during German Reunification in 1990 as the industrial and energy industries in former East Germany relied on energy intensive Soviet model.

On a regional level, the adhesion to the European Energy Charter in 1994 stimulated market liberalization. It also helped dismantling large conglomerates of electricity in the European bloc, prohibiting suppliers from participating in power distribution. The model adopted in Germany opened doors for wind and solar generators that still lacked competitiveness. By the time of Kyoto Protocol in 1997, the country committed itself to more ambitious targets than the EU. While the bloc proposed to reduce pollutant emissions by $8 \%$ over 1990 levels, Germany made the individual commitment of $21 \%$. (EUROPEAN COMISSION, 2017).

It is important to note that Chancellor Angela Merkel was in charge of the Ministry of Environment during Kyoto negotiations. The fact counts as an indication that the development of Energiewende extrapolates ideological or partisan divisions. Therefore it could be viewed as raison d'état and national interest. The environmental policy of conservative coalitions does not differ conceptually from the leftist proposals despite the differences regarding the nuclear issue and the extent of the state role (HAKE et. al, 2015).

In the United States, for instance, the cleavage between Democrats and Republicans persists with regard to the adoption of climate policies, as the latter tend to prevent legislation on environmental protection (FERREIRA; VIGEVANI, FERREIRA, 2012).

In 2002, the first fully left-wing coalition in West Germany, by Sozialdemokratische Partei Deutschlands (SPD) and the Bündnis 90/Die Grünen, also known as RedGreen Coalition, approved the closure of the national nuclear plants (Atomaustieg) by 2022. Although more motivated by the risk of accidents and toxic waste effects, and less by the level of pollution inherent in uranium mining, the socialist proposal placed Germany at the forefront of a clean energy system with less threat to human security.

Continuing the paradigm shift, the conservative coalition by the CDU/ CSU-Fraktion and the liberal Freie Demokratische Partei (FDP) adopted the “Energiekonzept” (DIE BUNDESREGIERUNG, 2010) in 2010. The document focused on making Germany one of the world most energy-efficient and climatefriendly economies, but the path should be gradual and market-oriented. The plan announced the postponement, for up to 14 years, of the closure of nuclear power plants, as atomic technology should serve as a bridge in the energy transition. 
The setback, called by the media as "Exit out of Exit" (DIE ZEIT, 2011), reflected the pressure of interest groups, notably the fossil segment, as well as the economic crisis and the austerity in the European bloc. While defending a non-fossil pattern, Merkel had always opposed the dismantling of the nuclear industry (SOKOL, 2005).

However, the return of nuclear policy did not avenge. Popular demonstrations, criticism by left opposition and the accident at the Japanese Fukushima plant in 2011 forced the government to rewind and shut down eight nuclear power stations that run with reactors built before 1980. The number of nuclear plants closed at once was equivalent to more than 50 percent of the entire national installations (DEUTSCHE WELLE, 2011). The Parliament approved the reversal by $80 \%$ of votes. One of the rejections votes came from Die Linke, the far-left party that advocated for an even faster dismantling (APPUNN, 2015). Since then, Energiewende has gained solidity and controversy.

\section{Development}

Wind and solar power are the central elements of the transformation, which increased the share of renewables in electricity generation from $4 \%$ in 1990 to $27 \%$ in 2014 (NOW, 2014, p. 5). Due to initial costs and intermittency that typically characterized these two industries at that time, the challenge was to innovate in technology and adopt regulations that would make the two sources more reliable and competitive. High costs, coupled with operational instability, would reduce public support and affect the export sector.

The solution required state intervention to ensure, through legislation, the priority of alternative sources in the distribution network despite the lack of competitiveness of renewable energy plants in its initial phase. In this sense, Energiewende exemplifies German ordoliberalism.

The central tenet of ordoliberalism is that governments should regulate markets in such a way that market outcome approximates the theoretical outcome in a perfectly competitive market (in which none of the actors are able to influence the price of goods and services)”. (DULLIEN, GUÉROT, 2012, p. 2).

The first mechanism applied was the feed-in tariff (FiT) laws of 1991, which established a tariff system for the protection of the renewable segment. The FiT 
guaranteed a fixed remuneration for 20 years and priority for green sources in the network of national power distribution. This regulation is a public incentive with great support from the political class (LAIRD, STEFES, 2009, p. 2622).

As energy from renewable sources may be more expensive in its early beginning, the legislation allowed the four major distributors (Eon, RWE, EnBW and Vattenfall) to buy expensive energy from green operators and resell it in the European Energy Exchange, which trades electricity, natural gas, permits for $\mathrm{CO} 2$ emissions and coal through spot and derivative contracts. Final consumers such as residences, commerce, services and non-energy intensive industries pay for the difference between wholesale and stock market prices. That marks the first imbalance in the distribution of costs, an inequality that fuels much criticism.

Other sectors that receive additional tariff exemptions are energy-intensive industries such as chemical and metallurgical, and factories that generate their own energy. These exceptions preserve the competitiveness of the giants, burdening small and medium-sized industries, residences, and commerce.

FiT tariffs were questioned in the European Court of Justice as a sort of subsidy and, thus, a violation of free trade rules. In 2001, the Court dismissed the claims as unfounded arguing that EU member states could oblige electricity distributors to buy clean energy at a price above market value as long as they repassed the costs to consumers. This interpretation also took into account the importance of renewable energy for the environment and the reduction of greenhouse gases that cause climate change (EUROPEAN COURT, 2001). Currently, more than two-thirds of European countries adopt some form of FiT (LAIRD, STEFES, 2009, p. 2244).

In July 2016, German Parliament approved reforms, maintaining the fixed remuneration system only for small producers, such as residences and commercial business that had installed solar panels on their roofs. Medium and large providers of clean energy must follow the market prices. Those reforms serve the interests of traditional generators and non-tariff-free industries; on the other hand, by maintaining fixed remuneration mechanism for smaller producers, the government aims to guarantee operational and political support from the population. The economic sustainability of the Energiewende will be under test from now on as the visible hand of the state reduces its intervention.

The project receives increasing support from the population, although this varies according to economy mood: more than $90 \%$ support Energiewende (WETTENGEL, 2016). The popular participation is not restricted to ideas and voting, as residential consumers bear much of the extra costs. By 2013, households 
contributed $€ 8.3$ billion of the total $€ 23.6$ billion spent on electricity, although residential consumption was only a quarter of the total (NOW, 2014, p. 31). The same type of support is common among politicians, as $85 \%$ of Parliament voted in favor of related legislations (NOW, 2014, p. 9).

Decentralization is what favors German energy policy in comparison with similar experiences in other countries. It is possible to say that Energiewende is the most participative process of energy transition in a capitalist state, whose macro objective is to develop a policy based on environmental safer provision of energy, self-sufficiency and future competitiveness. It means energy security without geopolitical constraints.

One measure towards decentralization was to reduce monopolies in the energy generation and distribution sectors. Four energy giants - Eon, RWE, ENBH and Vatenfall - control the thermoelectric sector but split the renewable segment with industries, small businesses, cooperatives, project developers, farms and citizens. In 2013, small producers were responsible for $46 \%$ of renewable energy installed capacity, compared to $13 \%$ of large operators, and $41 \%$ of strategic institutions and investors (BORSCHERT, 2015).

Another relevant aspect is the decentralization achieved by placing the local distribution systems under the supervision of city councils and due to large community involvement in planning and fundraising. Individuals can invest from $€ 100$ to $€ 500$ in green energy generation projects, which promotes popular engagement in the defense of industry interests (BUCHAN, 2012, p. 10).

According to Quitzow et al. (2016), the development of state-of-the-art technology for renewable energies finds its roots in communitarian projects and in the economic model based on small and medium-sized businesses. Approximately $99 \%$ of the general enterprises in the country fit into the so-called Mittelstand, responsible for $55 \%$ of GDP (BUNDESMINISTERIUM FÜR WIRTSCHAFT UND ENERGIE, 2014).

Over time the green policy has been battling fossil-fuelled industries, politicians linked to traditional energy inside and outside the country, part of the liberal media and even radical environmentalist. For a renowned British magazine, Energiewende meant expensive energy and increased carbon emissions due to the replacement of nuclear by coal (THE ECONOMIST, 2014). "Although the share of renewable energy in the German grid has increased since the year 2000, CO2 emissions have also risen since 2009. Is Germany trapped in the Energy Transition Paradox?" (NOW, 2014). 
Virulent criticisms also come from the progressive side. Boisert (2013) acknowledges that Germany was pioneer, but he sees its energy leadership as one of today's most demoralizing ironies.

The Energiewende is not the swift, bold advance that greens imagine but a slow, timid, and inadequate response to the crisis of climate change. It represents a failure of nerve, a failure of imagination, and a failure of arithmetic. It is visibly failing now, and if it succeeds in all its stated goals it will still fail. It is failing for a simple reason: the environmental movement, whose signal triumph is its influence over energy policy, has rejected nuclear power-the best source of clean energy we have”. (BOISERT, 2013).

The figure below indicates that the emissions indeed increased between 2009 and 2010, which might having be caused by growth in oil (and coal) consumption as oil price fell during those years. Again between 2011 and 2013, what maybe reflected the sudden shutdown of some nuclear power plants.

Figure 2: Greenhouse Gas Emissions in Germany

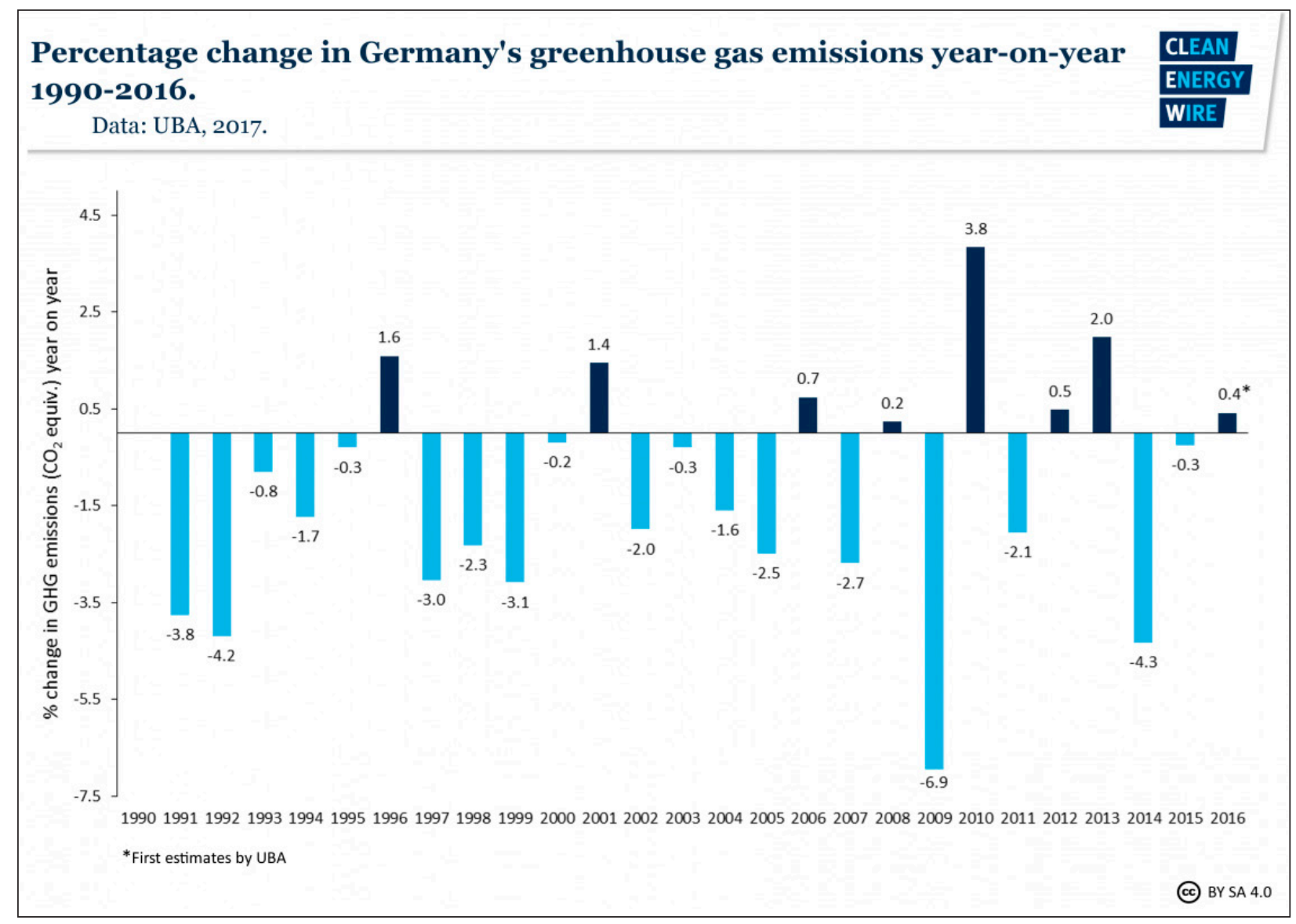

Fonte: CLEAN ENERGY WIRE, 2017 
The graphic information above reveals that 2016 was a negative year for German emission reduction target. Harsh weather, growing economy and increase in population - about 1 million refugees were allowed to live in the country in 2015 - could explain the downturn (WETTENGEL, 2016).

German energy policy has indeed many challenges. However, after more than 20 years of the resilient "Energie Konzept", the mixing system of fossil fuels and renewable energy has proven its maturation: today Germany has the world's most reliable electricity generation (BALL, 2017).

Many challenges need to be overcome, such as the distances between the wind farms concentrated in the north of the country and the urban and industrial centers in the south. The alternative is to increase and modernize the transmission lines. It happens that the modernization and the ideal functioning of the network depend on heavy and continuous investments as part of a long-term political and economic strategy.

Vaclav Smil argues that energy infrastructure is one of the most expensive investments in the world, and that the longevity and inertia of many energy enterprises make it impossible for any complex national system to reconfigure itself in three to four decades (SMIL, 2015). Quite a pessimistic view! Notwithstanding many obstacles, the prospects are shiny for German energy policy.

The direction of change is clear. At every stage since the 1970s, when the antinuclear movement saw the first stirrings of what would become the Energiewende, its ambitions have been dismissed as impossible to deliver. At every stage that has proved wrong. (...) The Energiewende has altered the energy mix in Germany and broken the old business model of the power-generating utilities. But there is much more to come (BUTLER, 2016).

\section{Energy foreign relations}

Sustainability alone does not explain such a radical policy. The foundations of Energiewende were also established in the quest for less energy dependence, more economic growth and in the search for the state of the art technology (QUITZOW et al., 2016, p. 2). With $61.4 \%$ dependence on foreign resources, energy policy means foreign policy for Germany. Therefore, the key word behind it is energy security in the sense of low vulnerability of any kind. 
Figure 3: Domestic production and imports

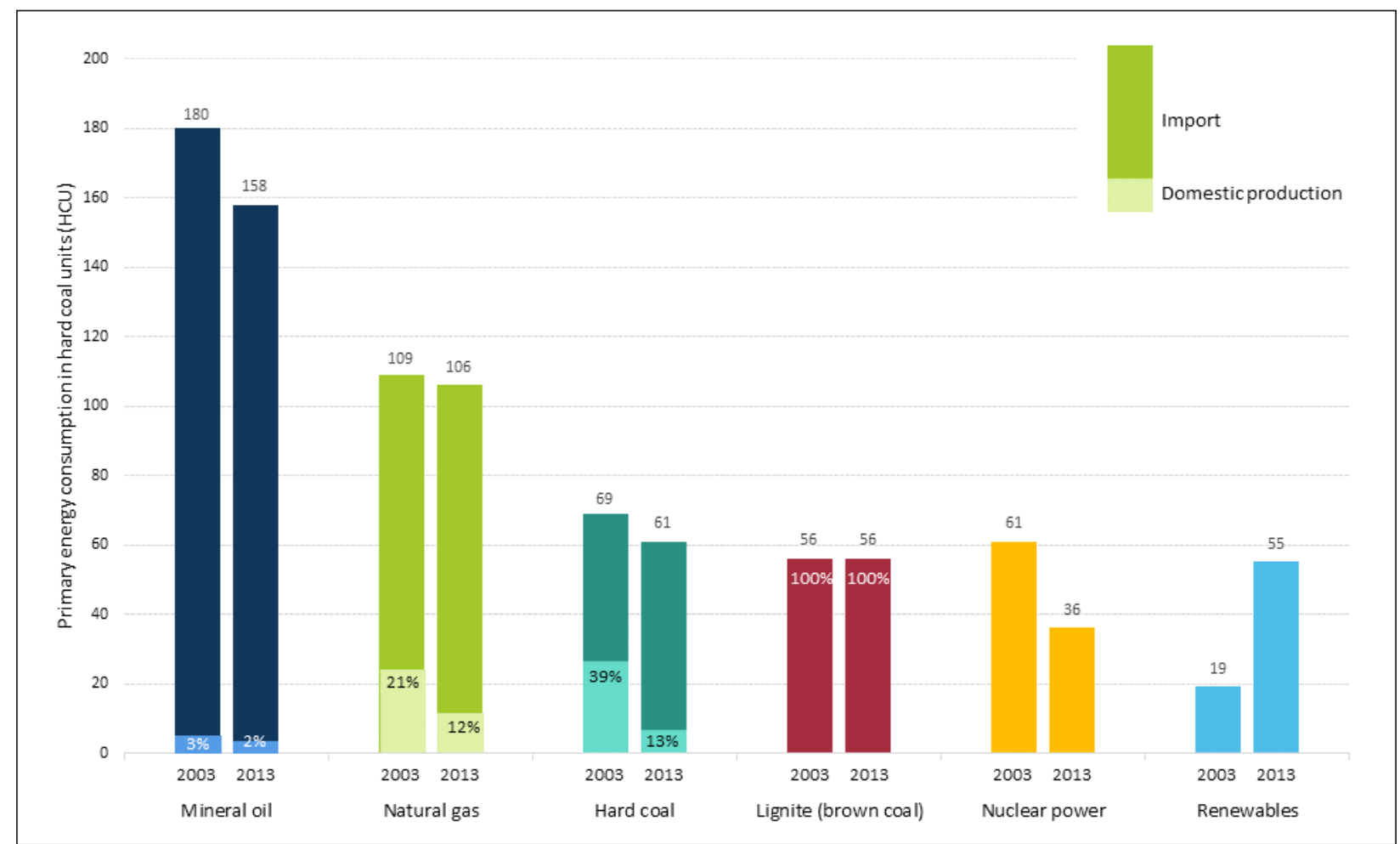

Source: WETTENGEL, 2016.

As gas in Germany is often used for heating, and not as much for electricity, Energiewende shall not affect imports in the medium term. Imported gas comes through western and eastern pipelines, with strong geopolitical implications in the second case.

The option for shutting down the nuclear power plants and the majority of the mining industries by 2050 should underscore the importance of Russian gas. Broadly speaking, Energiewende deepens relations with Russia for now and loosen them in the long term.

Energy security, environmental concerns and economic growth explain Germany's interest in keeping Energiewende and in becoming a major energy actor in its region as well as a green technology exporter.

One example of this effort is the creation of the Energy Export Initiative. Commissioned by the federal government since 2002, the program helps German companies to reach markets abroad.

To achieve these goals the country cannot depend on foreign fossil fuels anymore. Russian has been a reliable partner so far, but a large volume of oil comes from political instable areas such as the Middle East. Germany has coal reserves but the dirty mineral must be left behind if environmental health and climate change are considered. 
Therefore, part of the strategy is to become itself a reliable provider of electricity. In the first semester of 2017, Germany exported $11 \%$ of its electricity production to Central and East European countries (MORRIS, 2017).

Eventually, countries with low-cost renewable energy production will absorb regional green market shares and even compete with German industries in Germany. One-step in this direction is the EEG 2016, which allows neighbors states to supply renewable energy to Germany as long as they participate competitively in the auctions adopted with the reforms.

Maintaining and broadening the green shift in the next decades is crucial to Germany economy and overall security. This road has brought (and will keep bringing) opportunities for cooperation with countries such as China, which has pursued a similar energy transformation in the last years. This scenario, as shown in the next section, could also mean fierce competition in the next phase of industrialization.

Besides the economic gains indicated in this paper, Germany also enjoys the benefits of green energy as soft power. Apart from being an active player in all UN climate change negotiations so far, the country has expanded global governance in renewables.

One year after the first oil shock, the secretary of State of the United States, Henry Kissinger, proposed an international institution to organize and defend the interests of oil consuming countries. The plead led to the creation of the International Energy Agency to increase predictability in order to avoid geopolitical constraints and market disruptions. Considering its focus on finite resources and rather negligent concern with renewables, the organization could also be named "International Fossil Agency".

A similar institution for green energy was not created until Germany tried to test its soft power by convincing other countries that Energiewende could be replicated worldwide.

A remarkable initiative to develop renewable energy abroad was the creation of the International Renewable Energy Agency (IRENA), an international organization whose existence is the result of German efforts at intergovernmental level. In 2007, while using its presidency on the EU Council and the G8, Germany started to work for the creation of an organism outside the UN, where powerful forces blocked any proposal of that kind. 
While Germany successfully promoted a 20\% target for the expansion of RE in the EU, the 2006 and 2007 sessions of the UN CSD proved to be a serious blowback for the German strategy to promote RE on a global scale. Instead of approving the desired time-bound targets for a global share of RE, the session resulted without any agreement. While already an increasing number of G77 supported RE, the Gulf States let by Saudi Arabia blocked a decision underlining the importance of RE. After this experience, the Environment Ministry decided to change its strategy. Instead of trying to push RE within the $\mathrm{UN}$, it decided to work on the creation of a new international organization for RE outside of the UN framework, uniting like-minded countries. Under the aegis of Karsten Sach, Deputy Director-General for International Cooperation, the Environment Ministry mobilized political support within the German Government. Together with the Development Ministry and the Ministry of Foreign Affairs, it started an international campaign for IRENA's creation (ROHERKASTEN; WESTPHAL, 2013).

IRENA was finally developed in 2008 without the support of many countries, including the emerging nations such as China, India and Brazil. The first two signed to it later, but Brazil still resists membership as IRENA focus on solar and wind, while the country favors hydropower and biofuels. Today, IRENA has 150 members and 27 are under process of becoming members.

Reproducing German green transition in other countries is definitely a challenge. Low credit, underknowledge and the lack of an appropriate domestic political system might block any chance in many nations. Who knows?

Specialists like Vaclav Smil are deeply pessimistic with renewable capacity to adequately scale in order to satisfy energy demand in our modern societies.

I like renewables, but they move slowly. There's an inherent inertia, a slowness in energy transitions. It would be easier if we were still consuming 66,615 kilowatt-hours per capita, as in 1950. But in 1950 few people had air-conditioning. We're a society that demands electricity $24 / 7$. This is very difficult with sun and wind.Look at Germany, where they heavily subsidize renewable energy. When there's no wind or sun, they boost up their old coalfired power plants. The result: Germany has massively increased coal imports from the US, and German greenhouse gas emissions have been increasing, from 917 million metric tons in 2011 to 931 million in 2012, because they're burning American coal. It’s totally zany! (SMIL, 2013).

As the next section points out, more optimistic views show otherwise. 


\section{Green industrial transition}

Beyond regional gains, Energiewende might place Germany in a broader competitive condition if global climate governance advances. A comprehensive agreement as intended in COP 21 (Paris Agreement) would raise fossil costs, favoring German industries to the detriment of many competitors in industrialized countries. Both solar and wind industries have a high initial capital investment, but the marginal cost approaches zero after depreciation.

As one of the global leaders in green technology, the country has achieved this position by making huge R\&D investments (private and public) in renewable energy. Germany has strengthened its capacity to export products and services for manufacturing solar and wind devices, trying to turn itself from a fossil fuels dwarf into a green energy power.

Political studies on renewable energy focus the economic losses and gains for different sectors and on how partisan agendas reflect the preferences of voters and interest groups. In other words, (domestic) politics guides the discussion. Normally absent from international relations analysis - except in debates about climate governance - the issue is seldom observed from an international power politics perspective.

A transition to green energy paradigm requires attention to the dynamics of international politics on multiple levels such as economic, finance, trade, technology, law, environment, human rights, and many others. Besides, one must not forget the tight industrial competition among countries and on how energy security (cheap, reliable and abundant) may define winners and losers.

For decades, the definition of security energy prioritized fossil fuels and its implications for international security and world stability. After so many resource wars in last and current centuries, few would disagree that - even in times of abundance - fossil fuels are potential conflict-triggers. Mainly due to unequal geographic distribution of resources that brings nations to geopolitical disputes or to permanent dependence on highly politicized market.

German trajectory finds cooperation and competition with other industrial powers such as China, which is inserted in the select group of countries that seek to promote profound changes in energy systems. In 2015, China led global investments in renewable energy, followed by the United States, and far ahead of Germany and Brazil, respectively in sixth and seventh position (FRANKFURT SCHOOL-UNEP CENTER / BNEF, 2016). 
Among the ten largest investors in this ranking, Brazil and Germany were the only ones that reduced investments in 2015 compared to the prior year. In the Brazilian case, the economic and political crisis that has been affecting the country since then explain the fall. As for Germany, the reduction could be related to uncertainties regarding the future of FiT, a proof that domestic system may not be enough mature to be guided only by the invisible hand of the market.

In the United States, renewable energy sector gained emphasis during Obama administration. As the democrat President expressed in the State of the Union Address of 2010, "the nation leading the clean energy economy will command the global economy" suggesting that the United States should empower itself to the role.

Despite the roller coaster of legislations that allowed and withdrawn incentives for renewables after 2013, the U.S. the country invested $\$ 44$ billion in clean energy in 2015. The current scenario, however, discourages investments as President Donald Trump promises to increase production of non-renewable sources and to create jobs in the fossil sector.

As Republicans control both Houses in Congress after Trump's election, it will not be difficult for the President to deliver on campaign promises by discouraging growth in renewable energy sector. If this perspective is confirmed, the U.S. will step back from what Matthews (2017) calls the "green shift".

In the author's view, green transition means the destruction of an energy system based on the exploitation of fossil resources, characterized by geographic concentration, high production costs and geopolitical risks. On the other hand, the manufacturing of renewable energy is justified by the reduction of costs, geographic decentralization (energy produced anywhere and at any time) and the absence of geopolitical threats. "The green shift is the latest episode of this process of Schumpeterian industrial evolution", he argues.

It encompasses more than energy policies on moral grounds. The main purpose of the green shift is to achieve energy security and economic leadership in the 21st century, when manufacturing costs will be the determining factor in industrial competition.

A paradox of our times is that, while libertarian ideas of small government gain track, a country with overwhelming state presence on economic activity leads investments in renewables. I refer to China, which in 2015 invested $36 \%$ of the global total, an amount equivalent to US\$ 102 billion.

The cooperation in trade and technology between Germany and China was crucial for transforming the Chinese energy system. By acquiring German products 
and services, China was able to start its own green transition and to become the world leader in manufacturing of solar and wind energy.

Actions taken by the United States and the European Union against China in the World Trade Organization - for alleged subsidies and dumping practices in Chinese solar and wind industries - indicates the extension of the competition. Beijing has tried to avoid those complaints by relocating part of its premises in other countries.

Despite its divergent political system, are countries such as Germany and China betting on clean energy to overcome environmental constraints, but also as a strategy for a new stage of industrial capitalism? Are both nations investing in the energy innovation that will sustain Kondratieff's sixth wave (MATTHEWS, 2012), and reorganizing the productive base of the next world system leadership (ARRIGHI, 1995)?

Matthews (2016) argues that future industrial leadership will only be achieved through green shift.

Some advantages of renewable energy are not at all obvious and need to be made explicit. Fundamentally, they are scalable and can be built in a modular way - a solar panel, 100 solar panels, 1000 solar panels. As they are replicated in this way, their powers continue to rise without cutting efficiency. This cannot be said of nuclear reactors, which have an optimum operational size - below or above which the plant is underestimated. Furthermore, as they scale, they do not present greater and greater risks. Instead, they are relatively benign technologies with no serious risks... More importantly, the superiority of conventional renewable energies lies in their cost reduction trends, which are linked to the fact that they are always manufacturing and production products Where economies of scale actually play a role. This means that they offer true energy security, insofar as manufacturing can in principle be carried out anywhere (MATTHEWS, 2016).

The author points out, however, that the green transformation is being mainly driven by emerging countries such as China and India. Energy policies of these states do not reflect a sense of morality, but "strategies of national development of priorities". The rationality behind this strategy has less to do with public policies, corporate interests or demand, and more with cost reduction that green energy systems bring to power sector and to agricultural and industrial activities.

In a scenario of intense industrial competition that shall mark the current century, the cost factor will be decisive for the industrialization and deindustrialization 
of countries. Emerging nations in the East face the limits of growth, as fossil resources do not increase in the scale needed for the economic development of gigantic countries such as India and China. In addition, resource exploitation requires involvement in geopolitical issues that add costs of a different nature, such as military security.

In "Greening of Capitalism: How Asia is driving the next great transformation" Matthews (2015) says that the third phase of Industrialization will determine whether the industrial way of life will be able to continue providing (unequally) wealth and well-being without destroying the planet. The answer does not lie in moral principles of environmentalism or market opportunism.

A major structural transformation of capitalism requires state direction. Considering the characteristics of Chinese political system, despite its authoritarianism, China presents itself as the country with the potential to lead the great transformation.

Capitalism is the vibrant technical-economic system that allows such industrial dynamics. There is really no secret about why China is seeking abundance of energy and resource security through its highly targeted industrial strategies. The only mystery is why the West allows it to win in the competition unleashed in the international political economy. Changing the policy emphasis so that it engages directly with the economy through industrial strategy and changing the rationality of renewable energy to building energy security through its manufacturing would be an advance to restore some equilibrium (MATTHEWS, 2015).

Those arguments are extensively detailed in his recent book "Global Green Shift: When Ceres meets Gaia”. Renewable energy and information technology for green energy system is ate the center of what Schumpeter would call a sixth wave of creative destruction. It is not only a matter of substituting one technology for another, as neoclassical economists would say; it is about reviewing the industrial paradigm of our civilization (MATTHEWS, 2017).

\section{Conclusion}

The article explained German energy policy, known as Energiewende, from its historical perspective and pioneering. Some aspects differentiate German strategy from other examples in Europe and in the world. 
One factor is the active role of the state in planning and implementing legislations, infrastructure and incentives. The project survived successive government changes throughout the years, proving that its rationality is beyond partisanship.

Other factor is the participation of social actors, such as individuals, farmers, cooperatives and small entrepreneurs. Besides paying for higher electricity, those stakeholders get direct involvement in green initiative either by installing small solar and wind generators in its properties or by financing many of the projects.

Energiewende is also unique for its commitment to dismantle all nuclear plants until 2022, an ambitious target that faces resistance of many economic groups and implies more consumption of gas in the short term. Taking into account Germany's poverty in indigenous gas production, the replacement of nuclear by gas increases its dependence on Russia, a gesture that triggers a lot of criticism nationally and internationally.

Notwithstanding many barriers, Energiewende turned Germany from an energy dwarf into a regional power supplier. The new condition and its prospects has explained some changes in Germany's foreign policy toward East Europe recently, as in the case of Ukraine.

Maintaining the plan requires investments in modernization, infrastructure and adequate regulations, a challenge that faces constant skepticism among much of its opponents.

However, by implementing a profound energy transition Germany could place itself among a select group of countries that will lead a new phase of industrial capitalism. A pursue of "green shift" not on moral or environmental grounds but as a quest for economic and political power.

\section{Bibliography}

AGORA. Understanding the Energiewende FAQ on the ongoing transition of the German power system Background. October 2015. Available in: https://www.agora-energiewende. de/fileadmin/Projekte/2015/Understanding_the_EW/Agora_Understanding_the_ Energiewende.pdf. Accessed in: 02.02.2017

APPUNN, Kerstine. The history behind Germany's nuclear phase-out. Clean Energy Wire. 24 Jul 2015. Available in: https://www.cleanenergywire.org/factsheets/historybehind-germanys-nuclear-phase-out. Accessed in: 01.04.2016. 
ARRIGHI, Giovanni. O Longo Século XX: dinheiro, poder e as origens de nosso tempo. Rio de Janeiro: Editora Unesp, 1995.

BALL, J.. Germany’s High-Priced Energy Revolution. Fortune. 2017. Available in: http:// fortune.com/2017/03/14/germany-renewable-clean-energy-solar/. Acesso em?

BOISERT, Will. Green Energy Bust in Germany. Dissent. Summer, 2013. Available in: https://www.dissentmagazine.org/article/green-energy-bust-in-germany. Accessed in: 07.02.2017.

BORSCHERT, Lars. Citizens' participation in the Energiewende. Clean Energy Wire. 10 Mar. 2015. Available in: https://www.cleanenergywire.org/factsheets/citizensparticipation-energiewende. Accessed in: 14.08.2016.

BUTLER, Nick. The power behind the shift to renewable energy in Germany. Financial Times. November 7, 2016. Available in: https://www.ft.com/content/31474df4-a2ab11e6-82c3-4351ce86813f. Accessed in: 09.02.2016.

BUCHAN, David. The Energiewende: Germany's gamble. The Oxford Institute for Energy Studies. SP 26. June, 2012. Available in: https://www.oxfordenergy.org/wpcms/ wp-content/uploads/2012/06/SP-261.pdf. Accessed in: 21.05. 2016.

BUNDESMINISTERIUM FÜR WIRTSCHAFT UND ENERGIE. German Mittelstand: Motor der Deustchen Wissenschaft. 2014.

CHERPA, A.; JEWELL, J.. The concept of energy security: Beyond the four As. Energy Policy. Volume 75, December 2014, Pages 415-421. Available in: https://www. sciencedirect.com/science/article/pii/S0301421514004960.

CLEAN ENERGY WIRE. Germany’s greenhouse gas emissions and climate targets. 2017. Available in:: https://www.cleanenergywire.org/factsheets/germanys-greenhousegas-emissions-and-climate-targets. Acesso em?

DEUTSCHE BANK. Germany's energy turnaround: Challenging for municipalities and municipal utilities.. DB Research. September 17, 2012. Available in: https://www. db.com/cr/en/docs/Germanysenergyturnaround.pdf. Accessed in: 06.08.2016

DEUTSCHE WELLE. German cabinet approves 2022 nuclear shutdown. Deutsche Welle. Available in: http://www.dw.com/en/german-cabinet-approves-2022-nuclearshutdown/a-15134028. Accessed in: 22.05.2016.

DIE BUNDESREGIERUNG. Energiekonzept für eine umweltschonende, zuverlässige und bezahlbare Energieversorgung. Bundesregierung. 28.10.2010. Available in: https://www.bundesregierung.de/ContentArchiv/DE/Archiv17/_Anlagen/2012/02/ energiekonzept-final.html. Accessed in: 08.08.2016.

DIE ZEIT. Atompolitik: Austieg aus dem Austieg aus dem... Die Zeit. 24. März 2011. Nr. 13/2011. Available in: http://www.zeit.de/2011/13/Regierungsvertrauen. Accessed in: 05.08.2016. 
DULLIEN, Sebastian; GUÉR, Ulrike. The long shadow of ordoliberalism: Germany's approach to the euro crisis. European Council on Foreign Relations. ECRF/49. February 2012.

EUROPEAN COMISSION. Kyoto 1st commitment period (2008-12). 2017. Available in: https://ec.europa.eu/clima/policies/strategies/progress/kyoto_1_en. Accessed in: 02.02.2017.

EUROPEAN COURT. Judgment of the court of 13 march 2001. Available in: http://eurlex.europa.eu/legal-content/EN/TXT/PDF/?uri = CELEX:61998CJ0379\&from = EN

FERREIRA, Solange Reis; FERREIRA, Kelly and VIGEVANI, Tullo. An overview of domestic aspects in US climate policy. Rev. bras. polit. int. [online]. ISSN 19833121., vol.55, n.spe, 2012, pp. 88-103. Available in: http://dx.doi.org/10.1590/ S0034-73292012000300006.

FRANKFURT SCHOOL-UNEP CENTRE/BNEF. Global Trends in Renewable Energy Investment 2016. Available in: http://www.fs-unep-centre.org (Frankfurt am Main). Accessed in: 31.08.2016.

HAKE, J.f. et al. The German Energiewende - History and Status Quo. Forschungszentrum Jülich, Institute of Energy and Climate Research - Systems Analysis and Technology Evaluation (IEK-STE), D-52425 2015, Jülich, Germany. Available in: http://www.fzjuelich.de/SharedDocs/Downloads/IEK/IEK-STE/DE/Publikationen/preprints/2015/ preprint_10_2015.pdf?_blob=publicationFile.

HÖGSELIUS, Per. Red Gas: Russia and the origins of European energy dependence. New York: Palgrave Macmillan, 2013.

KRAUSE, F; BOSSEL, H; MÜLLER-REISSMANN, K. F. Energie-wende: wachstum und wohlstand ohne erdol und uran: Ein Alternative Bericht. Frankfurt am Main: S. Fischer, 1980.

LAIRD, Frank A; STEFES, Christoph. The diverging paths of German and United States policies for renewable energy: Sources of difference. Energy Policy 37, 2009, p. 2619-2629.

MATTHEWS, John A. Greening of Capitalism: How Asia is driving the next great transformation. Stanford: Stanford University Press, 2015.

MATTHEWS, John A. The renewable energies technology surge: A new techno-economic paradigm in the making? Working Papers in Technology Governance and Economic Dynamics no. 44. 2012. Available in: https://econpapers.repec.org/paper/tthw paper/44.htm

MATTHEWS, John A. Why China is becoming a renewables super power, and the West is not. Renew Economy. 29 May, 2015. Available in: http://reneweconomy.com. au/why-china-is-becoming-a-renewables-super-power-and-the-west-is-not-15031/. Accessed: 07.02.2017. 
MATTHEWS John A. Why the future belongs to decentralised renewables. ReNewEconomy. 2016. Available in: http://reneweconomy.com.au/future-belongs-decentralisedrenewables-37294/. Accessed in: 14.01.2017.

MORRIS, Craig. Germany has surpassed its 2020 target for green power. Energy Transition. The Global Energiewende. 02.08.2017. Available in: https://energytransition. org/2017/08/germany-has-surpassed-its-2020-target-for-green-power/. Accessed in: 19.09.2017.

QUITZOW, L., et al. The German. What's Happening? Introducing the Special Issue. Utilities Policy, 2016 Available in: http://dx.doi.org/10.1016/j.jup. 2016.03.002. Accessed: 15.08.2016.

ROEHRKASTEN, Sybille; WESTPHAL, Kirsten. IRENA and Germany's Foreign Renewable Energy Policy Aiming at Multilevel Governance and an Internationalization of the Energiewende? Working Paper FG 8, 2013/01, September 2013 SWP Berlin.

SMIL, Vaclav. Revolution? More like a crawl. Politico. 05/26/2015. Available in: http:// www.politico.com/agenda/story/2015/05/energy-visionary-vaclav-smil-quicktransformations-wrong-000017\#ixzz4I9e2KxeL. Accessed in: 23.08.2016.

SOKOL, Lena. Germany: the career of Christian Democratic Union leader Angela Merkel. World Socialist Web Site. 9 July 2005. Available in: https://www.wsws.org/en/ articles/2005/07/cdu2-j09.html). Accessed in: 08.08.2016.

WETTENGEL, J.. German carbon emissions rise in 2016 despite coal use drop. Clean Energy Wire. 2016. Available in: https://www.cleanenergywire.org/news/germancarbon-emissions-rise-2016-despite-coal-use-drop

THE ECONOMIST. What has gone wrong with Germany's energy policy. December $14^{\text {th }}$, 2014. Available in: http://www.economist.com/blogs/economist-explains/2014/12/ economist-explains-10. Accessed in: 19. 05. 2016. 